\title{
The end of truth?
}

C W du Toit

Research Institute for Theology and Religion

University of South Africa

\begin{abstract}
As we are approaching the end of the ceniury, many ideas, systems, and certainties, previously taken for granted, seem to be questioned, altered and rejected. One of these is the notion of truth, which pervades the very fibre of Western thinking. Rejecting the relevant critique as simply a postmodern fad, this article proceeds to give attention to the questions regarding the end of religious, scientific, and metaphysical truth. Truth and power are dealt with, as well as the narrative nature of truth. The article concludes with reference to the functioning of truth in the South African context as manifested in the Truth and Reconciliation Commission.
\end{abstract}

\section{INTRODUCTION}

The issues about truth raise basic and persistent questions for humankind which ostensibly can never be finally answered. Since truth concerns our way of judging and evaluating, our worship and value systems and so on, it functions in a theoretic, existential and pragmatic way every day. Truth is multifarious and one can only try to explicate the different meanings within different contexts. Truth may refer to linguistic rules, the rules governing logical propositions, pragmatic truth, rhetorical truth, or perhaps religious, ideological, economic, political or existential truth. The notion of truth is linked to the notion of being. To answer the question of being is to get to the truth. We want the truth because we believe in truth and we feel that it is beneficial to all of us. It is almost impossible to try to explicate the multiplicity of theories on and beliefs in truth, or to trace its implicit and explicit manifestations in theology, literature, philosophy, ideology and so on.

Western philosophy has so often posed the questions: Why are we attached to the truth? Why the truth rather than lies? Why truth rather than myth or illusion? How is it that in our societies 'the truth' has been given this value, thus placing us under bondage (Allen 1993:150-151)? It remains difficult to answer these questions especially when one considers the persistent and dominant functioning of truth in society. 
Although we want to believe in the universal nature of truth, no final criterion for truth exists. In spite of many endeavours to establish such a criterion, such as experience, proof and general opinion, a further criterion has always been needed to support the previous one. Only within a pre-established context such as analytical philosophy can truth be established as that which is in agreement and without contradiction. Analytical philosophy, a specific metaphysical system or a religious theory, however, does not necessarily determine truth. It is also not possible to live in a consistently analytical manner. Even those who hold very sophisticated theories on truth, or pride themselves in being scientific and exact in their judgements, often fall back on very naive ideas of truth in decision-making.

What stands out clearly is Western (wo)man's unshakable belief in truth. Truth has played an enormous role in the process of industrialisation and the expansion of science and technology. Consequently many believe that truth will make all things better, improve our style of living, bring honour to the scientist, credit to the politician and so on. It functions as an Archimedes point in our language and thought. Without subjectively accepting and adhering to objective truth, no understanding is possible, no communication sensible and nothing concrete can be achieved.

The twentieth century has witnessed the triumph and decline of the notion of truth. The two world wars contributed to the feeling of despair in man's ability to really improve his world. Truth came to be challenged insistently.

\section{THE FIN DE SIỆCLE PHENOMENON: TRUTH AND ESCHATOLOGY}

As we approach the end of the twentieth century we find eschatologies flourishing again. Belief in the end of time seems to be as popular as belief in truth. Belief in the end of time helps many to find renewed meaning in life. Many people believe that truth will triumph in the end, that everything will become clear when the naked truth is revealed. This truth is not man's truth but the truth about man's truth. Eschatological truth is God's verdict on man's world.

But there are also those who do not believe that anything will be 'revealed' at the end, whenever the end may come. If anything is to be linked to the end of the century - and the end of time - then it is the end of truth. What is to be revealed at the end is not a new truth or the final truth but simply no truth. Along this line of thinking the idea of the end of truth can be considered as the end of God since God is truth. Belief in the end of truth can also be seen as the end of eschatology.

Truth is our drifting Archimedes point. It is the very honour and humiliation of being. We are not, however, en route to a neat explanation of all riddles and truth will not triumph in the end. Truth is celebrated, terminated, and reborn in a continuous process. The history of the quest for truth is the history of its repetition. In spite of all 
our endeavours we don't seem to come nearer to this rainbow. What is unique at the end of the twentieth century is that more strongly than ever before it is realised that there is no fixed, eternal truth any more and we have to settle for a contingent, historical truth.

The historical, contextual and contingent nature of truth gives it the quality of a lie. A lie is accepted as the truth for the time it is believed in. A lie pretends to give answers, to be real, to stand for things as they are. A lie is not recognised as one before its time is spent. When a lie is uncovered, truth stands out as that which was not, which did not exist and had the character of non-being. Uncovering a lie brings truth to the fore in its retrospective mode. In the Hegelian sense wisdom begins at dusk when the owl of Minerva starts her flight. At the end of a bygone era we normally admit that things were not quite as we had thought they were, that in many instances we had been misled. This is the time of wisdom. It was only at the end of World War 2 that the appalling nature of Nazism was recognised. This is also valid in the case of apartheid. At the end of the century we recognise that all we believed this century was not true, or is not held to be true any more. Our belief in truth in particular cannot be held to be true any more.

\section{THE END OF TRUTH?}

\subsection{A postmodern fad?}

In postmodernism truth is viewed by some to have come to an end. Malpas (1992: 295), for example, believes that postmodernism does not relativise truth, but denies the very possibility of the notion of truth. Truth has been replaced by the play of meaning, by discourse, power, by words and so on, and is not a significant part of the game any more. In postmodernity the concern for truth, the very meaning of truth and the criteria determining truth came to be seen as purely context-dependent. According to Griffin (1988:9) these reflections based on language, psychology, and the 'sociology' of knowledge are buttressed by philosophical doubts about whether there is a 'given' (as opposed to a constructed) element in perception and whether the notion of truth as correspondence between idea and external reality is even meaningful ${ }^{1}$.

The postmodern denies the existence of truth as an autonomous entity. There is no attempt to retrieve what has been denied or to reconstitute truth. In this sense the postmodern does not come up with a solution to the problem of truth. It simply negates modernism's claim to truth by indicating the preliminary nature of truth. The postmodern remains thus, according to Malpas, in the thrall of the modern and the crisis it brings with it. The crisis is simply postponed, and we await a new version of that crisis. The postmodern reaction is thus incomplete because it doesn't take us far in coming to terms with the problem of truth (Malpas 1992:296). 
But it was truth in particular as an exclusive transcendent notion that was rejected in the postmodern. Truth was rejected as the relation with any specific entity which took our speaking beyond the human into a unique reality transcendent to ours. The rejection of this relation does not imply the rejection of truth as such. It is a recognition of the boundaries of truth claims and the conditions under which they operate.

The notion of truth could be maintained, for example, under the precondition that truth is limited to the fragmented nature of our speaking. This fragmentation is the consequence of the denial of any notion of truth that may apply to all speaking. Within postmodernism the relation between speaker and listener, between reader and writer, has been complicated by fragmentation so that real encounter is inhibited. This reduces the relationship to a playful one where all reference becomes part of the game itself (Malpas 1992:298). One must bear in mind that speaking is possible even where meaning is fragmented, for meaning can always be reconstituted. In this sense it would still be possible to speak of truth, but it is a different notion of truth - one that does not refer to a world beyond us, although the world is implicated in the act of speaking and in writing. Truth is the ever-present possibility of connecting and of understanding utterances, different beliefs, and sign-systems (Malpas 1992:298).

In this sense it is untenable to totally deny the possibility of truth because this would effectively rob us of the capacity to speak, understand or judge.

\subsection{The end of religious truth?}

The end of truth implies the end or death of God because God is truth. The idea with this paper, however, is not to reintroduce an outmoded death-of-God theology. We know that the death-of-God theology came to an end with God still very much alive in many religions.

The end of religious truth is the end of any exclusive religious truth. This came pertinently to the fore through the impact world religions made on Christian theology. There is no universal criterion outside a specific faith to judge between religions. We know that religions cannot be proven to outsiders. No supra-religious norm exists by which religions can be evaluated. One cannot apply a standard extraneous to a specific religion by which it can be judged. Any norm to determine what true religion within a tradition is must be derived from that religion itself. One also cannot describe from without that which is only to be experienced from within (Vroom 1989:52). There are thus no strictly neutral grounds for the evaluation of religions. It is impossible to reject another religion for the very same reasons, for this rejection is connected to a specific religion (Vroom 1989:62).

One could ask whether the notion of truth as it functions in world religions cannot be a common denominator to bind religions together. Indeed there are interesting 
similarities among different religions. Vroom (1989:301ff) distinguishes five ways in which the notion of truth is used in religions. These ways are common to most religious traditions. Truth functions first as public knowledge (doctrinal), which is more or less the public teaching of a religious tradition, second as comprehended knowledge (veritates) where truth generates a degree of insight, third as practised knowledge (vera religio), which refers to the true religion in the sense of faith in practice and obedience to the rules of faith. Fourth, truth functions as the moment of understanding (intellectus verus), which denotes the true religious understanding through religious experience. Last, truth functions as the transcendent (veritas) where truth is applied to the God as the truth.

Religions do show family resemblances on many points. All take the same existentials into account; all introduce qualifications to the religious language; all point out kindred imperfections in humanity and so on. These similarities, however, dwindle before differences and believers of different traditions do not consider similarities a unifying factor.

It is incorrect to characterise religions in terms of a single basic conviction or truth. The truth claims of religions are not monolithic although they display family resemblances. Corresponding beliefs from one tradition cannot simply be equated with those of another. People do make truth claims about the nature of the transcendent, of humankind, and the world. These claims differ. The criteria for the assessment of religious truth claims are not of such a nature that what is true and what is untrue can be established intersubjectively ${ }^{2}$. Truth claims must do justice to experience. Beliefs which have not been experienced remain superficial. Experience and interpretation must always be considered together.

According to Vroom (1989:384), the most promising procedure for the evaluation of competing truth claims seems to be the consideration of whether a religious tradition gives due attention to all aspects of life (the existentials). This emphasises the existential and pragmatic aspects of truth. Truth in this sense is truthfulness, where the belief one holds influences one's lifestyle on an existential level every day.

The truth of religions must be seen as contextual, operating within the parameters allowed by tradition and confession, and influenced by historical circumstances. No single religious truth exists - only a multiplicity of truths within the various traditions.

\subsection{The end of scientific truth?}

The nature of modern science where truth is determined by a mechanistic, reductionistic, world-view is no longer accepted (Griffin 1988:13). Our views on science and truth are constantly changing. Science as a whole, according to Mooney (1991: 
294), is now coming to be seen as a far more relativistic project, influenced to a considerable degree by social ideologies and attitudes. Its imperialistic claim to be the single road to certain knowledge has thus been largely eroded, and it is increasingly being viewed as just one of the ways in which humans have sought to make sense of their world.

After the appearance of Kuhn's (1962:76ff) work it was realised that natural science could no longer claim to work with fixed ideas. It was engulfed in the same historical flux as the human sciences. From this point of view human ways of thinking about nature could no longer be the concern of a 'pure reason' transcending the contingent historical situation. All thinking should be seen against a historical, cultural and social background, as the work of finite beings dealing with particular problems in specific situations (Toulmin 1989:234-236).

Truth is not identical to science. Scientific language has the function of verbalising observations, formulating theories, explaining phenomena and not presenting a draft of truth. Empirical sciences produce probable findings and not ultimate truths. Scientific methodology is not appropriate for answering questions of value (Davis 1994:31). Scientific theories can be said to be true, not because they present us with a precise replica of the relevant natural phenomena, but because they make it possible for us to give a rational account of the natural entities, their states, relationships and interactions. Scientific theories reveal natural phenomena, as they manifest themselves to be independent of that theory (Kockelmans 1993:148).

Science cannot claim truth in the sense that its theories are universally valid. No scientific theory can claim universal validity out of hand, since this implies the possibility of replacing the knowing subject and this cannot be guaranteed universally as the knowing subject is not universally the same (Van Niekerk 1992:207).

Science plays its own game, as Lyotard (1984:40) indicated. Science cannot legitimatise language games other than the scientific ones. Scientific knowledge requires that only one language game or denotation be retained and all others excluded. The game of prescription, for example, escapes it. It is incapable of legitimatising itself.

Scientists who are sceptical of the truth value of human sciences with their narrative dimension must remember that scientific knowledge cannot know and make known that it is the true knowledge without resorting to the other narrative kind of knowledge which, from its point of view, is no knowledge at all (Lyotard 1984:29).

Modern science leaves behind the metaphysical search for a first proof of transcendental authority as a response to the question 'Who decides the conditions of truth?' It is recognised that the conditions of truth, the rules of the game of science, are immanent in that game, that they can be established only within the bounds of a debate 
that is already scientific in nature, and that there is no proof that the rules are good, other than the consensus extended to them by the experts (Lyotard 1984:29).

We have come to the end of scientific truth 3 in the sense that science gives access to the truth, a truth that is to be accepted universally, and must necessarily influence all other sciences.

\subsection{The end of metaphysical truth?}

The end of metaphysics as the end or completion of truth epitomises the development of the notion of truth in the West. To speak of the end of metaphysics, of truth, or the end of any other discipline for that matter, is not really possible since one can radically question the metaphysically determined sense of 'end' (Sallis 1986:17).

Nietzsche said of metaphysics that it is the science which deals with the fundamental errors of mankind - but as if they were fundamental truths. According to him a metaphysical world could exist; the absolute possibility of it can hardly be disputed, but one could do absolutely nothing with it. For one could assert nothing whatever about it except that it was an inaccessible, incomprehensible being-other; a thing with negative qualities. Even if the existence of such a world were never so well proven, it would be certain that knowledge of it would be the most useless of all forms of knowledge: even more useless than knowledge of the chemical composition of water is to a sailor in danger of shipwreck (Hollingdale 1968:39-40, 192). For Nietzsche, metaphysics is dead because God is dead, being is a fallacy, and the true world a fable.

The end of metaphysics was asserted by Kant when he indicated the completion of the metaphysical project. He stressed that no single metaphysical problem remained which had not been solved, or for the solution of which a key had not been supplied. According to Hegel, metaphysics would come to an end in the sense that its history would be gathered into the full actuality of spirit. The end of metaphysics is, as Heidegger indicated, not its termination, its failing to continue or its decline into some kind of impotence but rather its completion as a different kind of gathering which Hegel would call Aufhebung. The end of metaphysics as its completion includes simultaneously its displacement (Sallis 1986:19-21). The death of metaphysics can be compared to Heidegger's view of death where death is not the end of Dasein like a road which stops or fruit which ripens, but the extreme possibility of Dasein, which cannot be outstripped. What is left is the task reserved for thinking at the end of metaphysics (Sallis 1986:22-23).

The end of truth in its religious, scientific and metaphysical modes is perhaps only the end of a specific phase of viewing truth in the West. Developments in these fields influence the fibre of Western societies and open up the identity of the West to be redetermined in a process of exposure to new contexts of meaning. 


\section{THEORIES OF TRUTH ${ }^{4}$}

In discussions about truth, virtually all authors define truth in the sciences according to the correspondence theory of truth. The coherence and pragmatic theories are seen to be more concerned with the criteria that must be fulfilled within a certain context. Truth as correspondence, however, is truth of a certain nature, valid under certain conditions. Traditionally the correspondence theory of truth sees the essence of truth as the correspondence between judgement and object. This conception, according to Kockelmans (1993:143), is affected with serious difficulties. What is understood by agreement? The judgement must state the thing as it is, yet it can never become identical with the thing. The agreement is neither between two representations, nor between one representation and a 'real' thing, nor is it an agreement between two contents of consciousness. The agreement is rather one between the content of a claim about a thing and the thing in so far as this can be discovered by us, independent of our claim by means of some process of confirmation which is intersubjectively acceptable. The 'thing' manifests itself in a certain context of meaning.

We can claim only that our judgements state how things are, as seen from some limited context of meaning or, in the final analysis, from the perspective of the whole of meaning which we can conceive. Thus, every form of revealment implies some degree of concealment. By revealing one thing, we conceal another and by considering one perspective we neglect other similar perspectives. If, however, every human effort to reveal things just as they are implies various forms of concealment, then for us truth in principle is always connected with untruth. And yet we can still maintain that our claims are true to the degree that they reveal things just as they manifest themselves to be. If human beings could make truth claims totally independently of contexts of meaning which are limited and historical, final truth might have been possible. Truth will thus always be limited and finite and will be accompanied in principle by some lack of truth. Truth thus always remains open to revision (Kockelmans 1993:145).

It would perhaps be improper to overtax the contribution of truth theories to the problem of truth. Even the most popular theory of correspondence must be more relaxed and must acknowledge correspondence as not absolute, definite and comprehensive, but provisional, limited, contextual, and to some degree creative (see Kockelmans 1993:149).

\section{TRUTH AND POWER}

If God is truth then truth is God. In this view truth exists as an unshakable, unchangeable, eternal entity. The dominant truth, however, seems always to be the truth of the dominant group(s) in power. Truth is vested in theological and metaphysical power schemes. Truth is only outwardly independent of the group which holds the power. 
In the history of Western thinking truth was not considered to be a problem at all until Nietzsche started questioning truth. Nietzsche asked why we want truth and not rather untruth, uncertainty and even ignorance. He changed the classical mode where truth refers to being and instead bound truth to becoming and activity. He saw truth as power because what passes as true serves life somewhere. Ideas are good or bad depending on the activity or domination they facilitate, and since one knows no way of honouring an idea other than by calling it true, the first predicate with which it is honoured is the predicate true. What matters is not so much truth itself but the life, the power that it serves. Fitting or failing to fit is beside the point. The value for life is the ultimate decisive (Allen 1993:43-44).

Nietzsche mocks the idea of truth's inherent value as if there were an actual drive for knowledge that, without regard to questions of usefulness and harm, went blindly for the truth. The world of practical interests cannot be seen apart from what is held for truth. In this way Nietzsche turned the classical way of seeing truth literally on its head.

Foucault was suspicious of any universal truths. He rejected any external position of certainty that is beyond history and society. His main tactic was to historicise any supposedly universal category as human nature.

He knew that truth claims are always inescapably bound up with the epistemic drive for mastery and control, even (or especially) where it is masked behind a rhetoric of liberal-humanist values or emancipatory critique (Norris 1993:257). He speaks of the 'government of truth' which refers to the power over human conduct and way of living which Western societies have long extended to those authorised to speak from a position of knowledge and in the name of truth. This is a power we experience today above all as the truth of norms and chances, the expert's truth about what is average or deviant, safe or dangerous, same or different. A massive discourse of disciplinary expertise contributes to the government of conduct as never before, yet this discourse has not been legitimised either by contract, conquest or divine right. Political power is thus exercised whenever one person acts with a view to the government of another or others, and this is not always or even usually the work of state agents (Allen 1993:154155).

According to Foucault (1980:98) power must be analysed as something which circulates, or rather as something which only functions in the form of a chain. It is never localised here or there, never in anybody's hands, never appropriated as a commodity or piece of wealth. It is employed and exercised through a net-like organisation.

The new South Africa has turned away from being a state ruling through power to one that is being ruled by justice as described in the constitution and bill of human rights 5 . 
In the new South Africa one can expect to have an abundance of truth rhetoric from a new government. The constitution guarantees an open and democratic society based on freedom and equality. Thus transparency is demanded from all sectors of society because secrecy is the sworn enemy of all truth. But how transparent can society be and how obvious the truth? It depends on our discernment of authority and our courage to respond when the king is naked. With Foucault it is possible to replace truth with freedom.

Empowerment of others is possible through solidarity. Rorty sees a comparison between the idea that it is in one's own interest to be just and Christianity's claim that perfect self-realisation can be attained through service to others. Both sayings urge us to believe that what is most important to each of us is what we have in common with others. The springs of private fulfilment and of human solidarity are the same.

Rorty replaced the notion of truth with that of commonality or solidarity. This solidarity consists simply in our common capacity to suffer and feel pain. For him there is a thing such as moral progress in the direction of greater human solidarity. But that solidarity is not thought of as recognition of a core self, the human essence, in all human beings. It is rather thought of as the ability to recognise more and more the unimportance of traditional differences such as tribe, religion, race and customs when compared to similarities in pain and humiliation (Rorty 1989:192). This has important consequences for the South African context as will be seen when dealing with the Truth Commission.

\section{TRUTH AS STORY}

\subsection{Truth as metaphor}

The metaphoric nature of truth has been emphasised in Western thinking. Story is often an extended metaphor, where life is mimetically repeated to emphasise a certain message. As we live in language, so we live in stories and metaphors. Truth parades in metaphoric dress. Truth makes us bedouins, travelling through history, enjoying our truths (meadows and plains) while they last. Sooner or later we have to take down our tents and move on. Truth is the tavern where we find refuge in the storm of uncertainty; it is the mask we wear by social agreement, the sea voyage which never seems to end (Blumenberg, in Van Wyk 1994:199ff; 202ff)).

Postmodernism has demonstrated the metaphoric nature of all communication, thereby shattering the untenable assumption of the logic of identity (Zelechow 1993: 122). Metaphor opposes the harmony of identity by stressing difference and by creating new meaning. 


\subsection{Truth as story}

We understand ourselves and our world as a story. Story means the unfolding development of narrative meaning by which what is past becomes meaningful in terms of what is present and what is projected in future. Life is uncovered in our stories. Story is the mode of our being in the world. This unfolding of life in the mode of story is the 'essence' of truth. Truth is not that which is unfolded or revealed, but simply the unfolding process itself (see Gelven 1990:125). This fits well the Heideggerian perspective of truth as a process of unveiling.

However, not any story or any inquiry will unfold truth. A 'false' story is not one which reveals misinformation or uncovers a wrong understanding of an essence; rather a false story is one which does not reveal at all. The metaphor of 'unfolding' stresses truth as a dynamic movement and not a static relationship between a cognitive subject and a known object. The real is to unfold and the unfolding itself is truth. Truth is no longer a mere servant of knowledge, or a predicate of a sentence. It is not merely a different name given to reality, nor is it equated with a fact. Because it is the unfolding of reality it is not restricted to representations (Gelven 1990:125-128).

In the disintegrated world of modernity, however, it is difficult for stories to be told and counsel to be conveyed. The story is dead. Without the story we are no longer able to communicate our experiences. We cannot tell our lives any more. Our lives have been taken from us. There are no experiences left as the modern world seems to destroy the foundation of real human experience from which the true story grows (Andersson 1993:164-165).

Wisdom as the epic side of truth has lost its ground in a society where language is reduced to the prolific exchange of information in a technocratic world. According to Benjamin's philosophy of history (see Andersson 1993:164ff) our historical world is not intelligible within the dialectic of Hegelian dynamics and telos. The wreckages of history seem to leave us with nothing but barren structures, deprived of any final meaning. Regarded as text the field of historical action has lost uniformity and meaningful continuity. It seems impossible to approach history as the story of mankind (Andersson 1993:169).

The notion of memory gives us access to an experience of history in its discontinuity. The redemptive power of the image is then to be traced back to what was not fulfilled, to what the directionality of historical action has forgotten (Andersson 1993:173).

It is thus through storytelling that we are healed. 


\section{THE FUNCTIONING OF TRUTH IN THE TRUTH COMMISSION ${ }^{6}$}

Every society faces the problem of its own legitimation. There are many ways to find legitimacy. It is normally done through a process of self-justification, by appealing to some ideal of justice, truth, a divine origin, or through suffering. The discourse of self-legitimation becomes an interpretative model for the self-understanding of that specific society.

In a post-apartheid society suffering is a special form of legitimation and in particular binds together all who suffered because of their racial disposition under the old system. People who suffered because of their race not only identify with some extreme stories of suffering, but also claim these stories for themselves. The unjustified suffering of the innocent in particular gives them the right to retributive, or as it is called, affirmative action.

One must acknowledge that one of the motives behind the insistence on a truth commission is to get access to these stories and so enhance the legitimation of the policies of government, the process of retributive action, and unacceptable actions of youth groups who are still suffering because of atrocities of the past. It also identifies government as keen to seek and maintain truth.

These stories also serve as symbols of understanding, helping people to understand what happened to them in the past, so as to cope in a new present. Perpetrators must face those whose loved ones they killed, face the enormity of the pain and suffering they caused others, and recognise the immorality and inhumanity of their deeds. These stories must be told so as to ensure that these deeds are never committed again. One can only agree with this passion, and we will presumably never have a repetition of an Auswitch, Dachau or an apartheid government, although one could expect human cunning to fabricate new and weird atrocities, under cover of 'new truths' being told. We must distrust truth in any society. A sense of justice and respect for truth is concomitant with even the most tyrannical, oppressive or degrading regimes (Balcomb 1993:252).

On the white side these stories of truth may instil feelings of guilt and of being an accomplice to the deeds of the past. If you has not suffered because of your race you are automatically part of those who instilled the suffering. Of course there was a lot of truth operative under the previous government. Foucault reminded us that truth is not outside power. Truth is a thing of this world: it is produced only by virtue of multiple forms of constraint (Allen 1993:150). It was part of the previous government as it will be part of the present government.

Truth, as belief in the apartheid system, was adhered to and clung to because of the security it offered. The fact that so many people so quickly changed their minds under a new government stresses that truth to a large extent has to do with self-interest. 
Truth is determined, like power, by a complex of strategic relationships which are socially conditioned. It does not function in abstraction. With a new set of social conditions in a post-apartheid era the set of truth standards of the apartheid era simply doesn't count any more. People who find it difficult to switch from one set of standards to another are liable to reject truth altogether.

For example, it is remarkable to note that Auschwitz and Dachau in particular contributed to the realisation among Europeans, and especially among Germans, that modernism, and with it truth, had come to an end. Of course Hiroshima and Nagasaki contributed to this feeling, but to some extent the massacre of the Jews was more intense in its prolonged sustenance of the killings, the premeditated nature of it and the concentration on a specific people, and so on. Auschwitz was a revelation of nihilism, but also of the destruction of humanity at the hands of modernity. Auschwitz fitted in perfectly well with the gist of modernity. If God died at Auschwitz at the hands of the modern and the rational, then so it seems did the possibility of truth. Nazism achieved the destruction not only of truth but also of the hope of modernism (Malpas 1992:291292).

Apartheid did not depend only on a modern world-view; it claimed science and religion as witnesses to its truth. The question is to what extent the disillusionment in the 'truth' of the apartheid era will contribute to a total disbandonment of the notion of truth.7 Security forces were give carte blanche for the sake of the 'safety' of whites, and had a free hand under cover of so many states of emergency.

But can the Truth Commission be free of prejudice and political motives? The Truth Commission as proposed will be of a religious and judicial nature - the two powers symbolising truth in our country. While the judicial task will be to uncover, the religious responsibility will be to conceal through forgiveness and indemnity. The principle is reconciliation through truth, redeeming our memories, not setting up Nürnberg-type of trials, but providing an opportunity to confess and be cleansed. This is, however, a forced kind of confession, because you can be brought to trial if you do not come to the fore and a victim tells a story that involves you. It must be remembered that most of the torturing that took place in the past happened in the absence of witnesses. In the absence of witnesses victims are dependent on the confession of the perpetrators.

Remorse, however, is no prerequisite for confession. As an example of the healing that is promised, other nations are studied. They were 'healed' in absolving nearly all of those who were involved in return for knowing what happened in darker days.

Ironically, so many people were tortured under the apartheid era by security officials who wanted to get the truth, and knew that the way to truth was possible only through torture (DuBois 1991:47-62; Norris 1993:257ff). 
That truth remains tinted is seen in the acceptance of indemnity for deeds of some freedom fighters, while it is insisted that those who thought they were 'only doing their duty' must be taken to task.

What we want is the truth, the whole truth and nothing but the truth. By getting the truth through the Commission the Sowetan (12 January 1995:12) believes that confidence in discredited institutions such as the security forces and government in general will be restored. The idea must be that after the Truth Commission has uncovered the past - that is the lies of the past - we will in future have a clean government and security forces which can be trusted.

In this whole effort truth is sought on various levels for different reasons. Those who have lost a son or beloved one are involved on a personal level. There are also those who want the truth for the sake of political and power expedience. As Sylvia Jele (Weekend Star 5 February 1995:8) said: 'I don't seek revenge, I just want to know why and how my son was killed.' But when legalism takes over, our brains become befuddled; we forget why we started down the road in the first place. Most probably Sylvia will never get the answer she expects, because the reasons given will be foolish ones which, however, will have made perfect sense in the context in which they were given. There is a truth that belongs to all, although it was known only to a few. It is the kind of truth that concerns our freedom. Truth that inhibits our freedom must be criticised and truth that advances freedom must be promoted ${ }^{8}$.

\section{THE FUTURE OF TRUTH}

Truth must lead to freedom. Empowerment of all means the multiplication of truth. If all are to be empowered, then everyone has a right to the truth. This does not mean that no universals exist. Universals, however, do acquire a unique identity within a specific context. Truth is simply the way we read reality, how we understand our world and ourselves. We tell these stories not in the belief of getting anywhere but simply to reflect on the place of our being.

Belief in truth as truth is belief in truth as the thing in itself (ding an sich). However, man himself is the Ding an sich according to Žiek (1991:200). It is we who posit the absolute and then start the never-ending search for it. Of course we can never find it, but we cannot give up this ideal. This makes it impossible for us ever to eradicate the paradox that marks our existence.

Truth is given with humanity. Although we cannot do without it, we can try to grasp its use and misuse, its importance and pretensions, its influence on us. We can never own truth; neither are we prepared to live without it. 
There will always be those who insist that they are telling the truth. And as Oscar Wilde said: 'If you persist in telling the truth you will be found out!' Then there are those who incautiously maintain that there is no truth and so nullify their own statement. We are indeed doomed to search for truth within our contingent historic contexts, where the truth we find according to our language rules and rules of logic and convention allows us to find some consolation. This will be coloured by the knowledge of the provisional nature of our time and place in history where we can do no better than to dimly reflect in a mirror.

\section{ENDNOTES}

1 This is maintained in realism, which holds the view that material objects exist externally to us and independently of our sense experience. Realism is thus opposed to idealism, which holds that no such material objects or external realities exist apart from our knowledge or consciousness of them, the whole universe thus being dependent on the mind or in some sense the mental (Devitt 1984:11-24).

2 Concerning the issue of interreligious verification and the question of whether neutral, universal human assessment of religious persuasions is possible, Vroom (1989:370ff) mentions the following conditions: Valid religious knowledge ought to be systematic, well-founded, intersubjective, discovered in freedom, and presented with a critical mind.

3 David Griffin (1988:8-9) rejects a radical postmodernist view according to which science neither gives nor seeks truth. He does acknowledge that science is not a value-free enterprise and that values other than rational and empirical ones essentially shape the world-view of the scientific community.

4 It is impossible to pay attention to the different theories of truth within the limits of this paper. Some aspects of the correspondence theory of truth are dealt with. For a general introduction, the work of Kirkham (1992:73-140) can be consulted.

5 One must remember Derrida's warning about the law when he said that the origin of authority and law presupposed a groundless violence, since there is no meta-standpoint from which the establishment of law and authority could be justified. On the contrary, the justification itself institutes, on the basis of a power operation, the order that it must justify. This, of course, makes the law indestructible. We must remember that the law is irrevocably transcendent to man precisely to the extent that it depends on man alone. It belongs to man and man alone, to give a concrete interpretation of law, without nay guarantee that this concretisation is the ultimate one.

The same goes for a bill of human rights. Human rights imply the idea of a human nature on which these rights are grounded. This nature is not some essence, given in itself, which can be grasped intuitively. On the contrary, it concerns a nature which man attributes to himself in human rights declarations and, furthermore, a nature whose definition must constantly remain open (see Van Haute 1993:263-267). 
6 The Truth Commission will have three committees:

* a Committee on Human Rights Violations, which will investigate and report on gross human rights violations 'committed in the course of the conflicts of the past';

* an Amnesty Committee to hear applications for and to grant amnesty to those who make full onfessions; and

* a Committee on Reparation and Rehabilitation, to make recommendations to Parliament on recompensing victims.

7 The same goes for the credibility of Christianity in South Africa. The tragic connection between Christianity and apartheid results in the complete erosion of any belief in a caring God or a relevant Christianity (see Nicolson 1994:409-419).

8 We cannot escape our freedom, no matter what it entails. Thus we must also face the radical contingency and replaceability of our truth as it operates in our language games. To shake off our finitude is to try to become God (Caputo 1983:666).

\section{Works consulted}

Allen, B 1993. Truth in philosophy. Cambridge: Harvard University Press.

Andersson, D T 1993. The end of the story, in Jasper, D (ed), Postmodernism, literature and the future of theology, 164-179. New York: St Martins.

Balcomb, A 1993. Third way theology. Pietermaritzburg: Cluster.

Caputo, J D 1983. The thought of being and the conversation of mankind: The case of Heidegger and Rorty. Review of Metaphysics 36/3, 661-685.

Davis, C 1994. Religion and the making of society. Cambridge: Cambridge University Press.

Devitt, M 1984. Realism and truth. Oxford: Blackwell.

DuBois, P 1991. Torture and truth. Routledge: New York.

Foucault, M 1980. Power/knowledge. New York: Pantheon.

Gelven, M 1990. Truth and existence: A philosophical inquiry. London: Pennsylvania State University Press.

Griffin, D R 1988. The reenchantment of science: Postmodern proposals. Albany: New York Press.

Hollingdale, R J 1968. Friedrich Nietzsche: Twilight of the idols and Antichrist. Harmondsworth: Penguin.

Kirkham, R L 1992. Theories of truth: A critical introduction. Massachusetts: MIT Press.

Knitter, F 1991. Beyond a monoreligious theological education, in Wheeler, B G \& Farley, E (eds), Shifting boundaries: Contextual approaches to the structure theological education, 151-180. Westminster: John Knox. 
Kockelmans, J J 1993. Ideas for a hermeneutic phenomenology of the natural sciences. Dordrecht: Kluwer Academic Publishers.

Kuhn, T S 1962. The structure of scientific revolutions. Chicago: University of Chicago Press.

Küng, H \& Tracy, D (eds) 1989. Paradigm change in theology: A symposium for the future. Edinburgh: Clarke.

Lyotard, J F 1984. The postmodern condition: A report on knowledge. Manchester: Manchester University Press.

Malpas, J 1992. Retrieving truth: Modernism, post-modernism and the problem of truth. Soundings 75/1, 287-306.

Mooney, C F 1991. Theology and science: A new commitment to dialogue. Theological Studies 52, 289-329.

Nicolson, R B 1994. Does Jesus save in South Africa? in Mouton, J \& Lategan B (eds), The relevance of theology for the 1990s, 409-420. Pretoria: HSRC.

Norris, C 1993. The truth about postmodernism. Oxford: Blackwell.

Rorty, R 1989. Contingency, irony, and solidarity. Cambridge: Cambridge University Press.

Sallis, J 1986. Delimitations: Phenomenology and the end of metaphysics. Bloomington: Indiana University Press.

Toulmin, S 1989. The historicization of natural science: Its implications for theology, in Küng \& Tracy 1989:233-241.

Van Haute, P 1993. Lefort and Derrida: The paradoxical status of human rights, in Kunneman, H \& De Vries, $\mathrm{H}$ (eds), Enlightenments: Encounters between critical theory and contemporary French thought, 259-271. Kampen: Kok.

Van Niekerk, A 1992. Rasionaliteit en relativisme. Pretoria: RGN.

Van Wyk, G M J 1994. Metaphéroo: Die metaforologie van Hans Blumenberg. DPhil-proefskrif, Randse Afrikaanse Universiteit, Johannesburg.

Vroom, H 1989. Religions and the truth: Philosophical reflections and perspectives. Michigan: Eerdmans.

Zelechow, B 1993. Nietzsche's theology of history and the redemption of postmodernism, in Jasper, D (ed), Postmodernism, literature and the future of theology, 120142. New York: St.Martin's.

Žižek, S 1991. For they know not what they do. London: Verso. 